\title{
Solvent-Free Microwave Synthesis of Trialkylphosphates
}

\section{LAALDJA MEDDOUR-BOUKHOBZA ${ }^{1}$, ABDELHAMID ELIAS ${ }^{2}$ and MOHAMED A. DIDI ${ }^{3 *}$}

\author{
${ }^{1}$ Faculty of Chemistry, University of Sciences and Technology of Alger, Algeria \\ ${ }^{2}$ Laboratory of Chemical Engineering, Faculty of Sciences, Boukhalfa University, \\ Tizi-Ouzou, Algeria. \\ ${ }^{3}$ Laboratory of Separation and Purification Technology, Tlemcen University, \\ Faculty of Sciences, Department of Chemistry, Box 119, Algeria. \\ ${ }^{*}$ Corresponding author E-mail: madidi13@yahoo.fr
}

http://dx.doi.org/10.13005/ojc/300131

(Received: December 13, 2013; Accepted: January 20, 2014)

\begin{abstract}
Trialkylphosphates are synthesized from alcohols by reaction with reactive phosphorus oxychloride under microwave irradiations and classical heating. Effects of these irradiations on the nature of the products and on the yield are studied. The compounds were characterized by their spectroscopic data and elemental analysis. The obtained results show that the products of these reactions are essentially trialkylphosphates and alkylphosphoric acids. They always show as the nature of the formed products and the yields in trialkylphosphates are comparable to those obtained in the classical conditions of heating. The speed of the reaction was increased by a factor from 40 to 120 .
\end{abstract}

Key words: Trialkylphosphates, Alkylphosphoric acids, Microwave-irradiation, solvent free.

\section{INTRODUCTION}

Trialkylphosphates are synthesized from alcohols by reaction with reactive phosphorus substances such as phosphorus oxychloride $\left(\mathrm{POCl}_{3}\right)$, Phosphorus pentachloride $\left(\mathrm{PCl}_{5}\right)$, and phosphorus pentoxide $\left(\mathrm{P}_{2} \mathrm{O}_{5}\right)^{1-3}$.

The main product of the reaction of alcohol with phosphorus pentachloride is trialkylphosphate. However, small quantities of dialkylphosphoric acid can be found in the reactional mixture.
These reactions are schematized according to the Scheme 1 and Scheme 2. The hydrochloric acid formed by this reaction, constitute the major inconvenience of this synthesis procedure, because it reacts with the trialkylphosphate to form the dialkylphosphoric acid. That generates the decrease of the synthesis yield in trialkylphosphates.

Among the different organophos-phorics, trialkyl phosphates, $\mathrm{PO}(\mathrm{OR})_{3}$, that are produced in important amount, are noticeably relevant and are widely employed in different technological areas as 


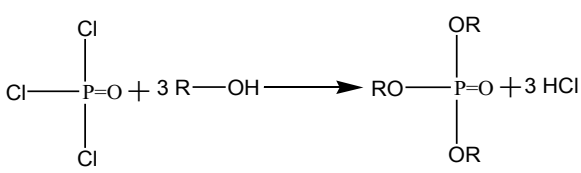

Scheme 1:

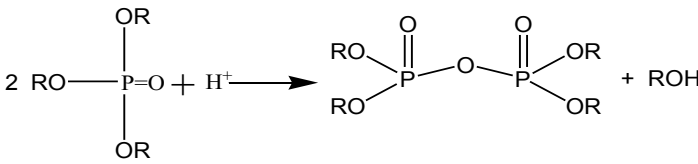

Scheme 3:

extractors of rare and radioactive elements, inhibitors of metal corrosion and polymer burning, additives to combustible and lubricating materials, brake-liquids, etc $^{4-6}$.

Other secondary reactions are possible, know the condensation reaction which from monophosphates forms pyrophosphates (Scheme 3).

Also, to avoid the reaction of desalkylation (scheme 2), the synthesis reaction (scheme 1) often is realized in the presence of pyridine that sets up $\mathrm{HCl}$ following the scheme 4 .

The pyridinium hydrochloride is easily separated from reactional mixture by washing to water. In the classical conditions of heating, the synthesis of the trialkylphosphates by this method necessitates several hours ( $3-4$ hours) of reaction and a domain of the temperatures between 80 and $95^{\circ} \mathrm{C}$. The slowness (some hours) of these reactions, which constitues the major drawback of this method of synthesis, generates interest in the activation of these reactions by microwave irradiations. We have already described the use of microwave activation in phosphorus chemistry ${ }^{7}$.

In this work, the heating of the reactional mixtures is carried out by microwave irradiations, of which the effects on the different operating conditions, the nature of the synthetic products and the trialkylphosphate yields will be studied and compared to the results obtained in the classic heating.

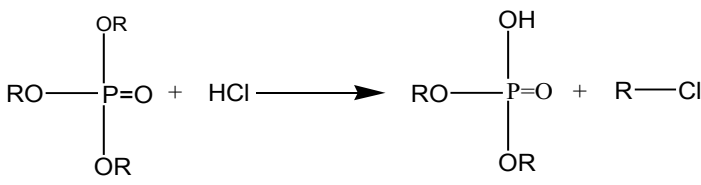

Scheme 2:<smiles></smiles>

Scheme 4:

\section{EXPERIMENTAL}

The reactions of synthesis under microwave irradiation were performed in a microwave oven Delonghi MW 75 working with the frequency of 2450 $\mathrm{MHz}$.

NMR spectrometry analyses were carried out on a spectrometer with Fourier Bruker AC 250 multinuclear. The infrared spectra were made on a FT IR Perkin Elmer 16 PC spectrometer.

Titrations were monitored with a Tacussel Mini $80 \mathrm{pH}$-meter with calomel electrode. The gas chromatography analyses were carried out on a Perkin-Elmer chromato-graphic apparatus, equipped with OV-17. The temperatures were respectively 250 , 200 and $300{ }^{\circ} \mathrm{C}$, in the injection port, column and detector (FID). The carrier gas flow of $\left(\mathrm{N}_{2}\right)$ is fixed at $30 \mathrm{~mL} / \mathrm{min}$. The analyzed products were diluted in the hexane.

\section{Reagent}

Reagents used were phosphorus oxychloride $\left(\mathrm{POCl}_{3}, 98 \%\right)$, 3-methyl-1-butanol $\left(\mathrm{C}_{4} \mathrm{H}_{9} \mathrm{OH}, 98 \%\right)$, 2-ethyl-1-hexanol $\left(\mathrm{C}_{8} \mathrm{H}_{17} \mathrm{OH}, 98 \%\right)$, octanol $\left(\mathrm{C}_{8} \mathrm{H}_{17} \mathrm{OH}, 98 \%\right)$, decanol $\left(\mathrm{C}_{10} \mathrm{H}_{21} \mathrm{OH}, 98 \%\right)$, 4-(1,1',3,3',tetramethylbutyl) phenol (4-ter-octyl phenol, $\left.\mathrm{C}_{8} \mathrm{H}_{17}-\mathrm{C}_{6} \mathrm{H}_{4}-\mathrm{OH}, 90 \%\right)$, pyridine $\left(\mathrm{C}_{5} \mathrm{H}_{5} \mathrm{~N}\right.$, $97 \%)$, heptane $\left(\mathrm{C}_{7} \mathrm{H}_{16}, 98 \%\right)$, hexane $\left(\mathrm{C}_{6} \mathrm{H}_{14}, 99 \%\right)$, and sodium hydroxide $(\mathrm{NaOH}, 99 \%)$, from Merck products.

\section{General Procedure}

Hydroxycompounds used in these reactions 
were 3-methyl-1-butanol, 2-ethylhexanol, decanol, and 4(1,1',3,3'-tetramethylbutyl)phenol.

Phosphorus oxychloride (2.5 g, (16.3 $\mathrm{mmol}$.$) ) and the hydroxycompounds ( molar ratio:$ hydroxycompounds/ phosphorus oxychloride = 3) were stirred in presence of solvent (heptane), and in presence or in absence of pyridine (molar ratio: pyridine/ phosphorus oxychloride $=3$ ).

The first synthesis step consists in to add successively in the reactor: the alcohol, the phosphorus oxychloride in the heptane and the pyridine. The addition operation was realized between 0 to $10^{\circ} \mathrm{C}$ and phosphorus oxychloride wa added slowly. The reactional mixture obtained was heated by the continuation by the two following methods:

\section{Classic Conditions of Heating}

The mixture above was heated and stirred under dry argon at $80^{\circ} \mathrm{C}$ for $2 \mathrm{~h}$.

\section{Microwave Irradiation}

The mixture was irradiated in a glass cylinder reactor (diameter $=3 \mathrm{~cm}$ ) fitted by a cooler filled with cooled octane $\left(0-5^{\circ} \mathrm{C}\right)$ according to the conditions (power and time) reported in Table I.

The reactional mixtures obtained were washed to water to separate the chlorhydrate of pyridine. They next were washed by an aqueous solution of soda (1\%) (Volume ratio: $\mathrm{NaOH} /$ reactional mixtures $=1$ ) to separate the secondary products (mono acids and residual dialkylphosphates). At T $=80^{\circ} \mathrm{C}$ and $\mathrm{P}=1 \mathrm{~atm}$, solvent was eliminated, then under vacuum $\left(\mathrm{P}=2 \mathrm{mmHg}, \mathrm{T}=75^{\circ} \mathrm{C}\right)$ to evacuate alcohol and residual waters. The reactional mixtures thus obtained are analyzed by different analysis techniques. The separation of the two obtained products (the di and trialkylphosphates) was carried out by chromatography, the pure product (trialkylphosphate) was characterized.

\section{Physical Properties of the trialkylphosphates} Synthesis of Tri 3-Methyl-1-Butyl Phosphate $\left(\mathrm{T}_{3} \mathrm{M}_{1} \mathrm{BP}\right) \mathrm{C}_{15} \mathrm{H}_{33} \mathrm{O}_{4} \mathrm{P}, \mathrm{n}_{\mathrm{D}}{ }^{20}=1.434$.

${ }^{31} \mathrm{P}$ NMR: $\delta / \mathrm{H}_{3} \mathrm{PO}_{4}(\mathrm{ppm})=0.08$.

${ }^{1} \mathrm{H}$ NMR: $\delta / T M S(p p m)=0.95\left(t, 18 \mathrm{H}, \mathrm{CH}_{3}\right)$, $1.52\left(\mathrm{~m}, 6 \mathrm{H}, \mathrm{CH}_{2}\right), 1.72(\mathrm{t}, 3 \mathrm{H}, \mathrm{CH}), 4.07(\mathrm{~m}, 6 \mathrm{H}$, $\left.\mathrm{CH}_{2} \mathrm{O}-\mathrm{P}\right)$.

IR: $v\left(\mathrm{~cm}^{-1}\right)=1014(\mathrm{P}-\mathrm{O}-\mathrm{C}), 1237(\mathrm{P}=\mathrm{O})$, $1368\left(\mathrm{CH}\left(\mathrm{CH}_{3}\right)\right), 1430\left(\mathrm{CH}\left(\mathrm{CH}_{3}\right.\right.$ et $\left.\left.\mathrm{CH}_{2}\right)\right), 2872$ \& $2959\left(\mathrm{CH}\left(\mathrm{CH}_{3}\right.\right.$ et $\left.\left.\mathrm{CH}_{2}\right)\right)$. tr (GPC)(min): 6.24.

\section{Synthesis of Tri 2-Ethylhexyl Phosphate} (T,EHP)

$\mathrm{C}_{24} \mathrm{H}_{51} \mathrm{O}_{4} \mathrm{P}, \mathrm{n}_{\mathrm{D}}^{20}=1.446$.

${ }^{31} \mathrm{P}$ NMR: $\delta / \mathrm{H}_{3} \mathrm{PO}_{4}(\mathrm{ppm})=-0.6$.

${ }^{1} \mathrm{H}$ NMR: $\delta / T M S(p p m)=0 . .89\left(\mathrm{t}, 18 \mathrm{H}, \mathrm{CH}_{3}\right), 1.28$ $\left(\mathrm{m}, 24 \mathrm{H}, \mathrm{CH}_{2}\right), 1.57\left(\mathrm{t}, 3 \mathrm{H}, \mathrm{CH}_{2}\right), 3.93(\mathrm{~m}, 6 \mathrm{H}$, $\left.\mathrm{CH}_{2} \mathrm{O}-\mathrm{P}\right)$.

IR: $v\left(\mathrm{~cm}^{-1}\right)=887$ et $1002(\mathrm{P}-\mathrm{O}-\mathrm{C}), 1263$ (al $\left.\mathrm{P}=\mathrm{O}\right)$, $1380\left(\mathrm{CH}\left(\mathrm{CH}_{3}\right)\right), 1463\left(\mathrm{CH}\left(\mathrm{CH}_{3} \& \mathrm{CH}_{2}\right)\right), 2874$, 2928 \& $2958\left(\mathrm{CH}\left(\mathrm{CH}_{3}\right.\right.$ et $\left.\left.\mathrm{CH}_{2}\right)\right)$.

$\operatorname{tr}(\mathrm{GPC})(\min ): 8.59$.

Table 1: Conditions of Synthesis and yields in trialkylphosphates

\begin{tabular}{|c|c|c|c|c|c|c|c|c|c|c|c|}
\hline \multirow{3}{*}{$\begin{array}{l}\text { Method } \\
\text { Product }\end{array}$} & \multirow{2}{*}{\multicolumn{3}{|c|}{$\begin{array}{l}\text { With pyridine } \\
\text { Under microwaves }\end{array}$}} & \multirow{3}{*}{$\begin{array}{l}\text { Classic } \\
-\eta(\%)\end{array}$} & \multicolumn{7}{|c|}{ Without pyridine } \\
\hline & & & & & \multicolumn{5}{|c|}{ Under microwaves } & \multicolumn{2}{|c|}{ Classic } \\
\hline & $P(W)$ & $t(s)$ & $\mathrm{T}\left({ }^{\circ} \mathrm{C}\right)$ & & $\eta(\%)$ & $P(W)$ & $t(s$ & & $\mathrm{T}\left({ }^{\circ} \mathrm{C}\right)$ & $\eta(\%)$ & $\eta(\%)$ \\
\hline 3-Methy-I-butanol & 450 & 10 & 79 & 57 & 55 & 630 & 25 & & 82 & 60 & 72 \\
\hline 2-Ethylhexan-1-ol & 270 & 75 & 88 & 53 & 75 & 270 & 70 & & 86 & 65 & 67 \\
\hline 1-Decan-ol & 900 & 35 & 72 & 62 & 55 & 900 & 45 & & 78 & 75 & 80 \\
\hline $\begin{array}{l}\text { 4-(1,1',3,3') Tetramethyl } \\
\text { butylphenol }\end{array}$ & 270 & 120 & 97 & 80 & 89 & 270 & 210 & 81 & 83 & 87 & \\
\hline
\end{tabular}

$\mathrm{T}$, temperature of the reactional mixture; $\mathrm{P}$, irradiation power; $\mathrm{t}$, time of irradiation; $\eta(\%)$, yield 
Synthesis of Tri Decyl Phosphate (TDP)

$\mathrm{C}_{30} \mathrm{H}_{63} \mathrm{O}_{4} \mathrm{P}, \mathrm{n}_{\mathrm{D}}{ }^{20}=1.452$.

${ }^{31} \mathrm{P}$ NMR: $\delta / \mathrm{H}_{3} \mathrm{PO}_{4}(\mathrm{ppm})=-1.70$.

${ }^{1} \mathrm{H}$ NMR: $\delta / T M S(\mathrm{ppm})=0.90\left(\mathrm{t}, 9 \mathrm{H}, \mathrm{CH}_{3}\right), 1.26(\mathrm{~m}$, $\left.48 \mathrm{H}, \mathrm{CH}_{2}\right), 3.97\left(\mathrm{~m}, 6 \mathrm{H}, \mathrm{CH}_{2} \mathrm{O}-\mathrm{P}\right)$

IR: $v\left(\mathrm{~cm}^{-1}\right)=894$ et $1028(\mathrm{P}-\mathrm{O}-\mathrm{C}), 1262(\mathrm{P}=\mathrm{O})$, $1378\left(\mathrm{CH}\left(\mathrm{CH}_{3}\right)\right), 1466\left(\mathrm{CH}\left(\mathrm{CH}_{3} \& \mathrm{CH}_{2}\right)\right), 2854$ \& $2923\left(\mathrm{CH}\left(\mathrm{CH}_{3} \& \mathrm{CH}_{2}\right)\right)$.

$\operatorname{tr}(\mathrm{GPC})(\mathrm{min}): 10.28$.

Synthesis of Tri [4-(1,1,3,3,-Tetra-methylbutyl) phényl] Phosphate (TOPPA)

$\mathrm{C}_{42} \mathrm{H}_{63} \mathrm{O}_{4} \mathrm{P}$

${ }^{31} \mathrm{P}$ NMR: $\delta / \mathrm{H}_{3} \mathrm{PO}_{4}(\mathrm{ppm})=-16.1$.

${ }^{1} \mathrm{H}$ NMR: $\delta /$ TMS $(\mathrm{ppm})=0.71\left(\mathrm{~s}, 27 \mathrm{H}, \mathrm{CH}_{3}\right), 1.33(\mathrm{~s}$, $\left.18 \mathrm{H}, \mathrm{CH}_{2}\right), 1.68\left(\mathrm{~s}, 6 \mathrm{H}, \mathrm{CH}_{2}\right), 6.76\left(\mathrm{~d}, 6 \mathrm{H}, \mathrm{CH}_{\text {meta }}\right.$ $\beta \mathrm{H}-\mathrm{H}=8.68 \mathrm{~Hz}), 7.24\left(\mathrm{~d}, 6 \mathrm{H}, \mathrm{CH}_{\text {ortho }}, \beta \mathrm{H}-\mathrm{H}=\right.$ $9.57 \mathrm{~Hz})$

IR: $v\left(\mathrm{~cm}^{-1}\right)=825$ et 960 (P-O-C), 1165 (PO-C arom.), 1200 (al. $\mathrm{P}=\mathrm{O}), 1360\left(\mathrm{CH}\left(\mathrm{CH}_{3}\right)\right), 1425\left(\mathrm{CH}\left(\mathrm{CH}_{3}\right.\right.$ \& $\left.\mathrm{CH}_{2}\right), \mathrm{C}=\mathrm{C} \& \mathrm{C}-\mathrm{C}$ arom. $), 2850$ et $2945\left(\mathrm{CH}\left(\mathrm{CH}_{3}\right.\right.$ $\left.\& \mathrm{CH}_{2}\right)$ ).

${ }^{*} \delta$, chemical shift; $v$, wave number; $s$, singulet; $d$, doublet; $\mathrm{t}$, triplet; $\mathrm{m}$, multiplet.

\section{RESULTS AND DISCUSSION}

Reactional mixtures obtained under microwave irradiations were confirmed by various techniques of analyses ${ }^{6}$.

The ${ }^{31} \mathrm{P}$ NMR has shown the presence of two important signals corresponding to tri [4-(1,1',3,3',-tetramethylbutyl)phenyl] phosphate (TOPPA $(\delta=-16.10 \mathrm{ppm}))$ and to di $\left[4-\left(1,1^{\prime}, 3,3^{\prime},-\right.\right.$ tetramethylbutyl)phenyl] phosphoric acid (DOPPA ( $\delta$ $=-9.11 \mathrm{ppm})$ ). Small signal corresponding to the secondary product (the pyrophosphates $(\delta=-12$ ppm) was also observed.

${ }^{1} \mathrm{H}$ NMR confirmed the formation of trialkylphosphates and the acid dialkylphosphoric acids with characteristic signals corresponding to the protons $\mathrm{CH}_{3}(\delta=0.9 \mathrm{ppm}),\left(\mathrm{CH}_{2}\right)_{\mathrm{n}}(\delta=1.2-1.6$ ppm), $\mathrm{CH}_{2}-\mathrm{O}-\mathrm{P}(\delta=3.8-4.1 \mathrm{ppm}), \mathrm{P}-\mathrm{O}-\mathrm{H}(\delta=7-8$ $\mathrm{ppm}$ ) and aromatic $\mathrm{C}-\mathrm{H}$ from $\mathrm{d}=7 \mathrm{ppm}$.

The infrared spectra have presented absorption corresponding to trialkylphosphates and the acid dialkylphosphoric acids groups: $\mathrm{P}-\mathrm{OC}$ and $\mathrm{P}-\mathrm{OH}\left(v=1030-1040 \mathrm{~cm}^{-1}\right) ; \mathrm{P}=\mathrm{O}(v=1260-1265$ $\mathrm{cm}^{-1}$; and the PO-H $\left(v=2300-2400 \mathrm{~cm}^{-1}\right)^{8}$.

The acid nature of dialkylphosphates was confirmed by the titration. The titration curves presented one slope shift corresponds to $\mathrm{pH}=5.8^{1}$. All the results of these analyses have shown that the products of the reaction of alcohol with phosphorus oxychloride, obtained under micro-wave irradiation, were identical to those obtained with the classic method of heating. In fact, the ${ }^{31} \mathrm{P}$ NMR has shown the formation of trialkyl-phosphates and the acid dialkyl-phosphoric acids according to Schemes 1 and 2.

Different trialkylphosphates are synthesized under microwave irradiations and by classic heating, and this in presence or in absence of pyridine. The yields and the different operating conditions are mentioned in Table 1.

The powers and the times of irradiation are fixed to obtain temperature near of the one applied in the classic heating $\left(80-97^{\circ} \mathrm{C}\right)$, recommended for the synthesis of alkylphosphates ${ }^{9-11}$.

The comparative study of the results of synthesis under microwave irradiation has shown that in presence of pyridine the synthesis yields were weaker than those obtained in absence of pyridine.

In absence of pyridine, the synthesis yields obtained by classic method of heating were higher to those obtained under microwave irradiation.

Nevertheless, the yields in the latter cases were lightly superior, although no precaution was taken to avoid the secondary reactions (scheme II). The short times of synthesis under microwave irradiation have not favored the secondary reactions, even to high temperatures.

Besides, the obtained yields under microwave irradiation were lightly inferior to those obtained under classic heating. The difference can be explained by the higher reduction of reaction time, from some seconds to $2 \mathrm{~h}$.

\section{CONCLUSION}

The products of the reaction of alcohols 
with the phosphorus oxychloride under microwave irradiation (with and without pyridine) were identical to those obtained by classic heating trialkylphosphates according to reaction 1 . The effect of the temperature was comparable in both methods of heating. The activation of reaction 1 by microwaves allows also to obtaining the higher yields. The speed of the reaction of alcohols with phosphorus oxychloride was $2 \mathrm{~h}$ in the classic conditions of heating, whereas under microwave irradiation, reaction took place in $25 \mathrm{~s}$ to
$3 \mathrm{~min}$; the ratio of speed increasing was 40 to 120 The decrease of the reaction time and the decrease of degradation products of trialkyl-phosphates are the main advantages of microwave irradiation.

\section{ACKNOWLEDGEMENTS}

We gratefully acknowledge the ATRST (Agence Thématique de Recherche en Sciences \& Technologie-Algérie) (ex ANDRU) for their financial support.

\section{REFERENCES}

1. Elias A., Didi M.A., Villemin D., Phosphorus Sulfur, 179: 1-9 (2004).

2. (a) Dorfman Y.A., Abdreimova R.R., Zh. Obshch Khim 63: 289 (1993). (b) Dorfman Y.A., Abdreimova R.R., Akbayeva D.N., Kinet. Katal. 36: 103 (1995). (c) Dorfman Y. A., Aleshkova M.M., Polimbetova G.S., Levina L.V., Petrova T.V., Abdreimova R.R., Doroshkevich D.M., Russ. Chem. Rev. 62: 877 (1993).

3. M. Gorjizadeh, M. Afshari and S. Nazari, Orient J. Chem., 29(4): 1627-1630 (2013).

4. Belkhouche N.E., Didi M. A., Romero R., Jönsson J. Å., Villemin D., J Membrane Sci, 284: 398-405 (2006).

5. Krea M., Khalaf H., Hydrometallurgy, 58:215225 (2000).
6. K. Sapna, N.K. Sharma and S. Kohli, Orient J. Chem., 28(2): 969-974 (2013).

7. Villemin D., Elbilali A., Caillot F., Siméon F., Jaffrès P.A., Mosaddek M., Hakiki A., J. Chem. Res., 433 (2003), and references cited.

8. Crutchfield M.M., Dungan C.H., Letcher J.H., Mark V., Van Wazer J.R., Topics in Phosphorus Chemistry (Interscience Publishers, New York, 5: 333-335 (1967).

9. Socrates G., Infrared Characteristic Group Frequencies (John Wiley, New York), p. 121 (1990)

10. Elias A., Azzouz A., Rodehuser L., J. Soc. Alger. Chim., 5: 89 (1995).

11. Elias A., Azzouz A., Rodehuser L., Phosphorus Sulfur, 27: 2055 (1993). 